\title{
Recent Advances in Blast Furnace Ironmaking in North America
}

\author{
W-K. LU1) and M.G. RANADE') \\ 1) Department of Materials Science and Engineering, McMaster University, Hamilton, Ontario, Canada L8S 4L7. \\ Products, East Chicago, IN, U.S.A.
}

2) Inland Steel Flat

(Received on November 11, 1990; accepted in the final form on January 25, 1991)

\begin{abstract}
A survey on blast furnace practices in American and Canadian steel companies in 1989 was conducted and aggregate data were reported. Recent developments in raw materials which contribute to improvements in blast furnace ironmaking are reviewed. Five blast furnaces, two large and three medium size, are described in more detail as examples. Comments are made on future developments in ironmaking in North America.
\end{abstract}

KEY WORDS: blast furnace process; ironmaking; hot metal; fuel rate; iron ore; iron; coke, pellet; sinter.

\section{Introduction}

In the last decade, significant progress in blast furnace ironmaking practice has been made in the USA and Canada. Further increases in the use of continuous casting, fewer blast furnaces per steel plant, escalating cost of re-lining, etc. have been among these contributing factors for the drive for better ironmaking practice.

In the modernization of a blast furnace operation, in general, efforts may be classified into three areas:

(a) Upgrading the quality of iron ore agglomerates and metallurgical coke, and materials handling,

(b) Upgrading the blast furnace and auxiliary facilities, and

(c) Reinforcement of technical staff and training of work force.

The 1980 's was a period of scale-down, rationalization and restructuring during which American and Canadian steel companies became more "lean and mean" in international competition. In general, progress made in (c) has been very limited. In area (b), capital investment is required. Progress in this area has been hindered by the ability to demonstrate cost effectiveness for these capital expenditures. Partly due to the fact that in an operation lacking stability, it is difficult to credit an improvement made to a specific change. Particularly, with inferior raw materials, the full benefit from investment in (b) and (c) would be uncertain. It leads to the observation that area (a) would be the first and fruitful step to modernization in respect to the state of current operation.

In the 1960's after two decades of research and development on pelletizing, American and Canadian steel companies enjoyed an improvement in iron ore quality at that time. Through the lean years of the 1980's, with over capacity, relatively cheaper energy and high interest rate, the pace in research and development on raw material slowed down significantly. Even though literature from overseas and academic institutions has raised questions about assessment and variation of qualities of acid pellets and the differences between acid and fluxed pellets, few tirals were conducted and often inconclusive. In these blast furnace trials, without a well established reference state, during a period of changing conditions, economic benefits of fluxed pellets could not be adequately quantified. As a result, it was not possible to secure funds necessary for converting the pellet plants to fluxed pellet production.

When large blast furnaces were built in North America, one of the very valuable experiences gained during the early stage of operations was that modern facilities alone would not necessarily lead to a stable and efficient operation. Very soon it became obvious that in order to operate large blast furnaces, raw materials must have better and more consistent qualities, e.g., at least stability of coke and reducibility of ore. Through laboratory tests and plant trials, advantages of fluxed sinter, fluxed pellets and coke of better coke strength after reaction (CSR) indices have been recognized and realized by many North American steel companies. Furthermore, the contribution from a more stable and smooth blast furnace operation to the overall economy of a steel plant is generally appreciated.

The anticipated shortage of coke supply in the years to come and another energy crisis which may be the consequence of current political crisis in the Mideast, could lead to the situation that large amounts of coal injection is not only a necessity technically but also an advantage economically. A higher level of sophistication in monitoring and control of blast furnaces is needed for larger amounts of coal to be injected. For the decade of the 1990's, more progress will be seen in areas (b) and (c) in the modernization of blast furnace ironmaking in the USA and Canada.

\section{A Survey of Blast Furnace Operations for 1989 in the USA and Canada}

The existing blast furnaces in the USA and Canada 
Table 1. A survey of operational data in 1989 of North American blast furnaces.

\begin{tabular}{|c|c|c|c|c|c|c|}
\hline \multicolumn{2}{|c|}{ Units } & \multirow{2}{*}{$\frac{\mathcal{N} *}{43}$} & \multirow{2}{*}{$\frac{\text { Mean }}{8.5}$} & \multirow{2}{*}{$\frac{\text { Std. Dev. }}{1.6}$} & \multirow{2}{*}{$\frac{\mathrm{Min}}{5.6}$} & \multirow{2}{*}{$\frac{\operatorname{Max}}{13.7}$} \\
\hline Hearth diameter & $(\mathrm{m})$ & & & & & \\
\hline Working volume & $\left(\mathrm{m}^{3}\right)$ & 43 & 1503 & 631 & 616 & 3739 \\
\hline Inner volume & $\left(\mathrm{m}^{3}\right)$ & 43 & 1689 & 785 & 693 & 4656 \\
\hline Top pressure & (atm) & 43 & 0.49 & 0.42 & 0.20 & 2.32 \\
\hline Acid pellet & $(\%$ of burden) & 40 & 58.3 & 31.2 & 10.0 & 99.0 \\
\hline Ore & ( $\%$ of burden) & 13 & 5.3 & 5.6 & 0.1 & 16.1 \\
\hline Sinter & ( $\%$ of burden) & 18 & 27.4 & 13.2 & 10.5 & 61.0 \\
\hline Sinter $\mathrm{CaO} / \mathrm{SiO}_{2}$ & & 15 & 2.2 & 0.7 & 0.9 & 2.9 \\
\hline Fluxed pellet & ( $\%$ of burden) & 19 & 61.8 & 32.9 & 1.0 & 100.0 \\
\hline Fluxed pellet $\mathrm{CaC}$ & & 13 & 0.90 & 0.04 & 0.81 & 1.2 \\
\hline Scrap & (\% of burder) & 34 & 4.3 & 3.1 & 0.7 & 11.9 \\
\hline Limestone & $(\mathrm{kg} / \mathrm{THM})$ & 19 & 43.5 & 34.2 & 0.0 & 143.5 \\
\hline Dolomite & $(\mathrm{kg} / \mathrm{THM})$ & 33 & 47.6 & 33.3 & 0.0 & 121.5 \\
\hline BOF slag & $(\mathrm{kg} / \mathrm{THM})$ & 31 & 56.2 & 41.4 & 0.0 & 181.0 \\
\hline Coke & $(\mathrm{kg} / \mathrm{THM})$ & 43 & 479.9 & 61.4 & 399.5 & 669.0 \\
\hline Oil & $(\mathrm{kg} / \mathrm{THM})$ & 19 & 52.9 & 17.3 & 10.0 & 80.5 \\
\hline Tar & $(\mathrm{kg} / \mathrm{THM})$ & 3 & 25.7 & 1.0 & 24.5 & 26.5 \\
\hline Natural gas & $(\mathrm{kg} / \mathrm{THM})$ & 23 & 31.9 & 12.4 & 10.0 & 58.5 \\
\hline Total fuel & $(\mathrm{kg} / \mathrm{THM})$ & 43 & 511.4 & 52.3 & 434 & 669 \\
\hline Productivity & $\left(\mathrm{T} / \mathrm{d} / \mathrm{m}^{3} \mathrm{WV}\right)$ & 43 & 1.86 & 0.35 & 1.12 & 2.53 \\
\hline Hot metal silicon & $(\%)$ & 43 & 0.76 & 0.23 & 0.40 & 1.33 \\
\hline
\end{tabular}

$* \mathcal{N}$ : Number of blast furnaces

including their sizes and capacities are listed in the Third Annual Blast Furnace Round-up. ${ }^{1)}$ It should be pointed out that a significant number of them are not operational. The operational data aggregated by American Iron Steel Institute for this review are listed in Table 1 .

\section{Raw Materials}

With the anticipated depletion of high grade hematite iron ores in Minnesota and Michigan, the pelletizing process was developed in North America to enable the use of low-grade Taconite ores. Iron ore pellets are now the single largest source of iron for North American blast furnaces. Pellets constitute about $70 \%$ of the blast furnace burden. In anticipation of a growing steel market, several new pelletizing plants were constructed in the $1970^{\prime}$ s, especially in Minnesota, Michigan and Quebec. In the beginning, productivity and cost were the major focus areas for these pellet plants. As the North American steel industry contracted in the 1980's, the pelletizing capacity became severely affected. The majority of pellet plants resorted to annual shut-downs during the winter, in light of the reduced demand. A number of plants were permanently shut-down. Driven by their customers' needs, operating costs and product consistency were the major criteria on which the pellet plants survived. Statistical process control techniques were vigorously applied. Until this time, physical strength, size distribution and chemical composition (silica content) were monitored. Blast furnace trials, particularly in the early 1980 's, established that metallurgical properties, such as the reducibility, had a significant effect on the blast furnace coke rate. ${ }^{2)}$
This led to an optimization of the pellet induration cycle and the use of organic binders to improve pellet reducibility. Blast furnace operators also demanded lower silica content and a closer control on pellet size distribution. This led to the installation of computerized mine planning, fine screening, grind control, and roller screens in a number of pellet plants.

In the mid 1980's, a number of pelletizing and blast furnace trials were conducted to evaluate the benefits of limestone-dolomite fluxed pellets. Towards the end of the decade, fluxed pellets had been firmly established as a major product, accounting for about $30 \%$ of North America's pellet production. The transition to fluxed pellets involved many changes in plant equipment (e.g., flux grinding mills, pre-heat burners) and practices. Each pellet plant has customized the fluxed pellet chemistry to meet their customer's blast furnace operation. As a result, there are pellet plants producing as many as four grades of pellets. North American pellets have changed from a commodity in the early 1970's to a custom-made product, meeting a customer's specific most demanding specifications in the 1990's. An example of the improvement achieved is shown in Fig. 1 and Table 2. North American fluxed pellets are now equivalent to the best sinter in terms of reducibility and softening meltdown properties and are superior in terms of strength and low temperature breakdown (LTD/ $\mathrm{RDI}$ ).

Relative importance of sintering plants, built in the late 1950's and early 1960's in integrated steel mills, declined in the 1970's due to a lack of suitable domestic ores, and growth in pelletizing. Now, there are a number of blast furnace operations in North America that do not use any sinter. However, 

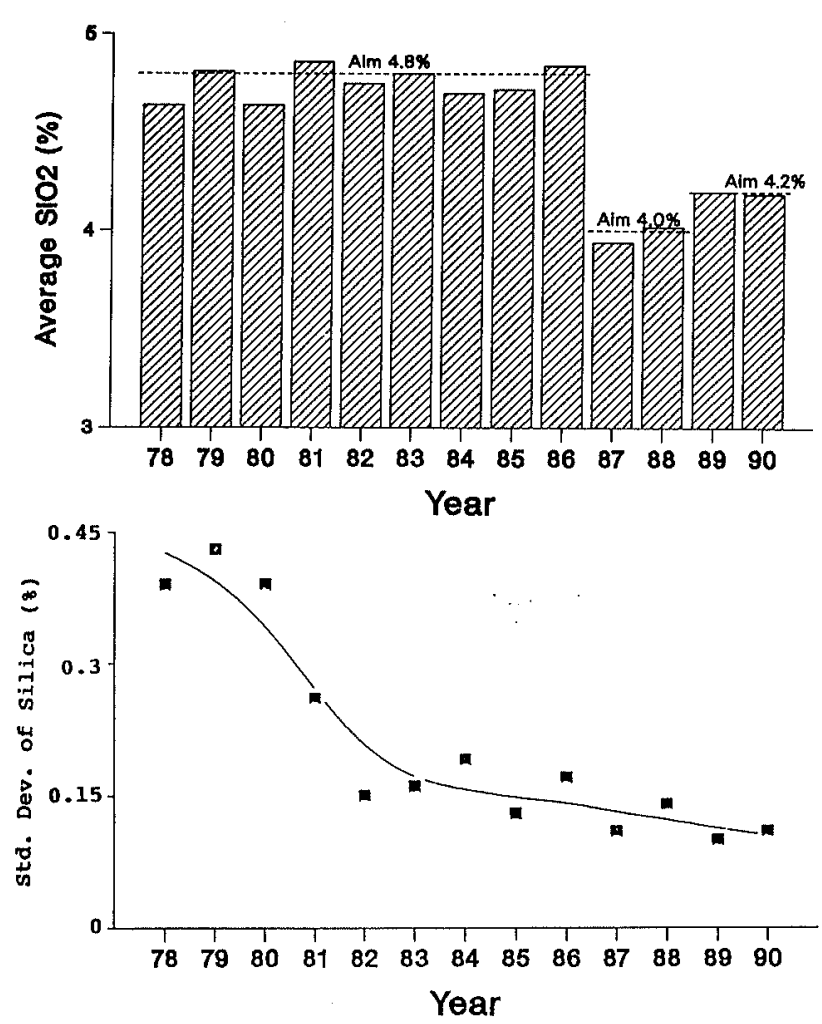

Fig. 1. An example of pellet quality improvement in Minorca Mine.

Source: Inland Steel

Table 2. An example of pellet quality improvement. (Minorca Mine, Minnesota)

\begin{tabular}{|c|c|c|c|c|}
\hline Type Binder & $\begin{array}{c}\text { Acid } \\
\text { bentonite }\end{array}$ & $\begin{array}{l}\text { Acid } \\
\text { organic }\end{array}$ & $\begin{array}{c}\text { Acid } \\
\text { organic/ } \\
\text { Limestone }\end{array}$ & $\begin{array}{c}\text { Fluxed } \\
\text { bentonite }\end{array}$ \\
\hline \multicolumn{5}{|l|}{$\begin{array}{l}\text { Chemical composi- } \\
\text { tion (Dry \%) }\end{array}$} \\
\hline $\mathrm{Fe}$ & 66.2 & 66.4 & 66.3 & 62.8 \\
\hline $\mathrm{SiO}_{2}$ & 4.8 & 4.5 & 4.2 & 4.2 \\
\hline $\mathrm{MgO}$ & 0.2 & 0.2 & 0.2 & 1.6 \\
\hline $\mathrm{CaO} / \mathrm{SiO}_{2}$ & 0.04 & 0.04 & 0.15 & 1.10 \\
\hline \multicolumn{5}{|l|}{ Properties } \\
\hline $\begin{array}{l}\text { ASTM tumble } \\
\text { index }(\%+6.35 \\
\text { mm })\end{array}$ & 95 & 94 & 95 & 96 \\
\hline Compression (kg) & 249 & 200 & 240 & 242 \\
\hline $\begin{array}{l}\text { ISO reducibility } \\
\left(R_{10} \% / \mathrm{min}\right)\end{array}$ & 0.95 & 1.1 & 1.1 & $1.3 *$ \\
\hline $\begin{array}{l}\text { ISO LTD }(\%+ \\
6.35 \mathrm{~mm})\end{array}$ & 91 & 90 & 93 & $97^{*}$ \\
\hline ISO swelling* (\%) & 16 & - & - & $<15$ \\
\hline $\begin{array}{l}110^{\circ} \mathrm{C} \text { contraction } \\
(\%)\end{array}$ & $28^{*}$ & - & - & 8.2 \\
\hline \multicolumn{5}{|l|}{$\begin{array}{l}\text { Softening-melt- } \\
\text { ing** }\end{array}$} \\
\hline$T_{s}\left({ }^{\circ} \mathrm{C}\right)^{*}$ & 1290 & - & - & 1440 \\
\hline$\Delta T_{s m}\left({ }^{\circ} \mathrm{C}\right)^{*}$ & 230 & - & - & 80 \\
\hline$\Delta P_{\max }(\mathrm{kPa})^{*}$ & $>10$ & - & - & $<2$ \\
\hline
\end{tabular}

* Limited samples

** $\quad T_{s}:$ Softening temperature

$\Delta T_{s m}:$ Softening-melting range

$\Delta P_{\max }:$ Max. pressure drop during melting

sintering operations provide a ready and effective outlet for recycling by-products of iron and steelmaking operations, such as mill-scale, pellet fines, flue-dust,
Table 3. Typical sinter compositions. (\%)

\begin{tabular}{lccc}
\hline & $\begin{array}{c}\text { Armco } \\
\text { Middletown }\end{array}$ & $\begin{array}{c}\text { Bethlehem } \\
\text { Burns } \\
\text { Harbor }\end{array}$ & $\begin{array}{c}\text { Inland } \\
\text { Indiana } \\
\text { Harbor }\end{array}$ \\
\hline Total $\mathrm{Fe}$ & 57.0 & 53.5 & 52.5 \\
$\mathrm{FeO}$ & 12.0 & 7.5 & 9.7 \\
$\mathrm{SiO}_{2}$ & 5.0 & 5.0 & 5.8 \\
$\mathrm{Al}_{2} \mathrm{O}_{3}$ & 1.2 & 1.4 & 1.5 \\
$\mathrm{CaO}$ & 11.5 & 13.2 & 12.1 \\
$\mathrm{MgO}$ & 2.0 & 3.1 & 3.5 \\
$\mathrm{~B} / \mathrm{A}$ & 2.2 & 2.6 & 2.1 \\
\hline
\end{tabular}

coke breeze, and steel slag. Recognizing this opportunity, external blending systems (located outside the sinter plant) were employed to mix these byproducts for producing a consistent quality sinter. Given that the majority of blast furnace burden consisted of pellets, fluxed and super-fluxed sinter with a basicity $\left[(\mathrm{CaO}+\mathrm{MgO}) /\left(\mathrm{SiO}_{2}+\mathrm{Al}_{2} \mathrm{O}_{3}\right)\right]$ as high as 4.5 , were produced in order to minimize the addition of raw flux to the blast furnace. The application of statistical process control, blending and mix-moisture control systems, and the use of burnt lime, improved sinter consistency and strength. Typical sinter compositions are listed in Table 3.

However, many sintering operations were not competitive with iron ore pellets in terms of cost. While some of this can be traced to old and inefficient facilities, accounting systems in use at the time, and the ability to sell or inexpensively dispose of the by-products mentioned above, also played a role. Excess pelletizing capacity, in conjunction with tightening environmental standards on $\mathrm{SO}_{x}, \mathrm{NO}_{x}$ and particulate emissions, spelled the demise of a number of sinter plants. In contrast, sinter plants built in the 1970's near modern blast furnaces were efficient and were in compliance with environmental standards by design. Access to an international waterway for the acquisition of ore made some of the sinter plants highly cost competitive with pellets. Bethlehem's Sparrows Point operations exemplify this.

While a number of studies have been completed on improvements in the metallurgical properties of sinter, due to blast furnace constraints prevalent in North America, the current emphasis still remains on sinter strength, chemical consistency and cost. At Inland Steel the sinter blend is designed to yield a product that is compatible with fluxed pellets in terms of metallurgical properties. Bethlehem ${ }^{3}$ (Table 4) and

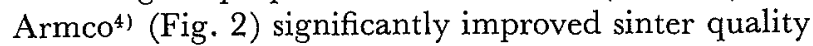
and production on the basis of blast furnace performance improvements attained. At Bethlehem's Sparrows Point sinter plant, olivine is used to enable the use of low-silica imported ores and to eliminate the need for dolomite flux. Generally, North American sinters now have a basicity of about 2 . Therefore, these sinters possess good strength, and excellent low temperature breakdown (LTD/RDI) and reducibility $\left(R_{40} / R I\right)$ characteristics by international standards. However, the relatively high basicity and $\mathrm{MgO}$ content of these sinters is likely to result in the deterioration of melt-down characteristics. 
Table 4. Effect of an increase in sinter charge on Bethlehem's Sparrow Point "L" Blast Furnace, 1982.

\begin{tabular}{ccc}
\hline Burden & $\begin{array}{r}46 \% \text { sinter } \\
50 \% \text { pellets }\end{array}$ & $\begin{array}{l}73 \% \text { sinter- } \\
19 \% \text { pellets }\end{array}$ \\
\hline Fuel rate (kg/THM) & 512 & 493 \\
Hot metal (\%) & & \\
Average Si & 0.71 & 0.57 \\
$\sigma_{\text {Si }}$ & 0.24 & 0.16 \\
Permeability & 1.72 & 1.88 \\
Burden movement & & \\
Hangs/day & 0.5 & 0 \\
Large slips/day & 48 & 0.3 \\
Small slips/day & 96 & 4 \\
\hline
\end{tabular}

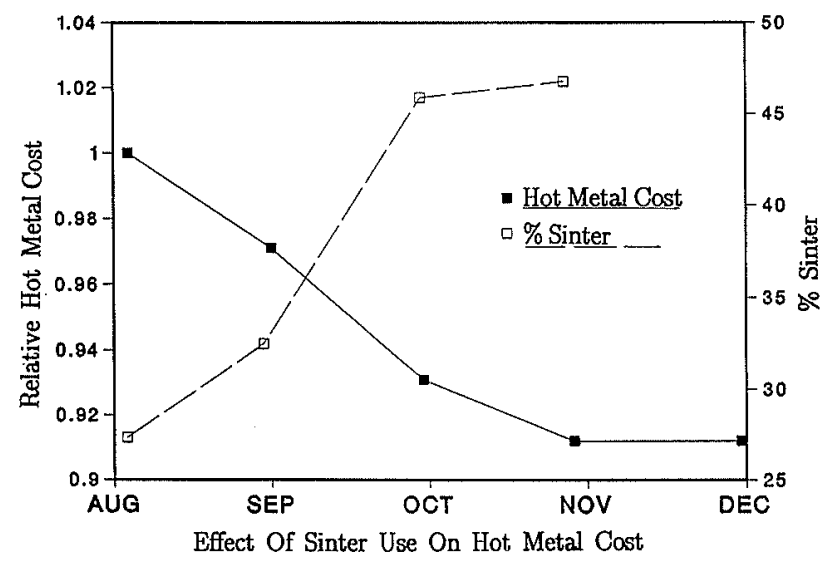

Fig. 2. The effect of sinter use on hot metal cost. Source: Armco

Recently, efforts have began to develop economical cold-briquetting processes to recycle steel mill by-products typically used in sintering. If these are successful and environmental restrictions become more severe, a contraction of sinter plant capacity in North America could be expected. A number of sinter plants are already in various stages of disrepair. The investment required for the repair, and environmentally-related expenditures may lead to the closure of these plants during the next 5-10 years. Alternately, sintering may prove to be a cost-effective method of recycling a greater variety of solid by-products of iron and steelmaking operations. This would allow investments in existing sinter plants in order to continue operation well into the next century.

Coke facilities in North American are relatively old (Fig. 3), with many batteries constructed in the 1960's and 1970's. In the $1970^{\prime}$ 's, coal petrography became an established tool for coal evaluation. With the help of pilot-scale tests and controlled plant trials, it was possible to link petrographic properties of individual coals and their proportion in the blend, to the physical properties of coke, i.e., the ASTM stability. ${ }^{5}$ As a result, significant improvement in coke stability and blast furnace performance was achieved. A number of trials in small blast furnaces were made with formed coke. ${ }^{6,7)}$ Typically, formed coke could be used satisfactorily up to $40 \%$ of the coke charge. However, this technology was not adapted due to the lack of a large-scale demonstration, and the economics prevail-

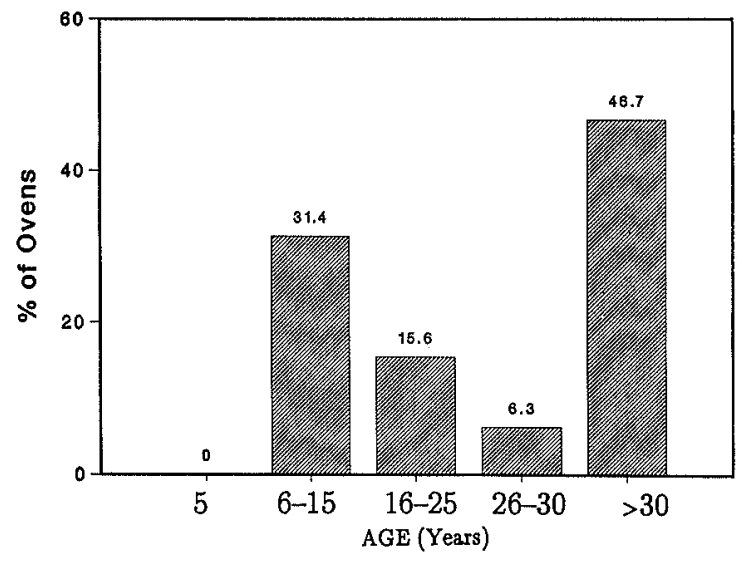

Fig. 3. The age profile of coke ovens in the USA and Canada at the end of 1988. Source: IISI

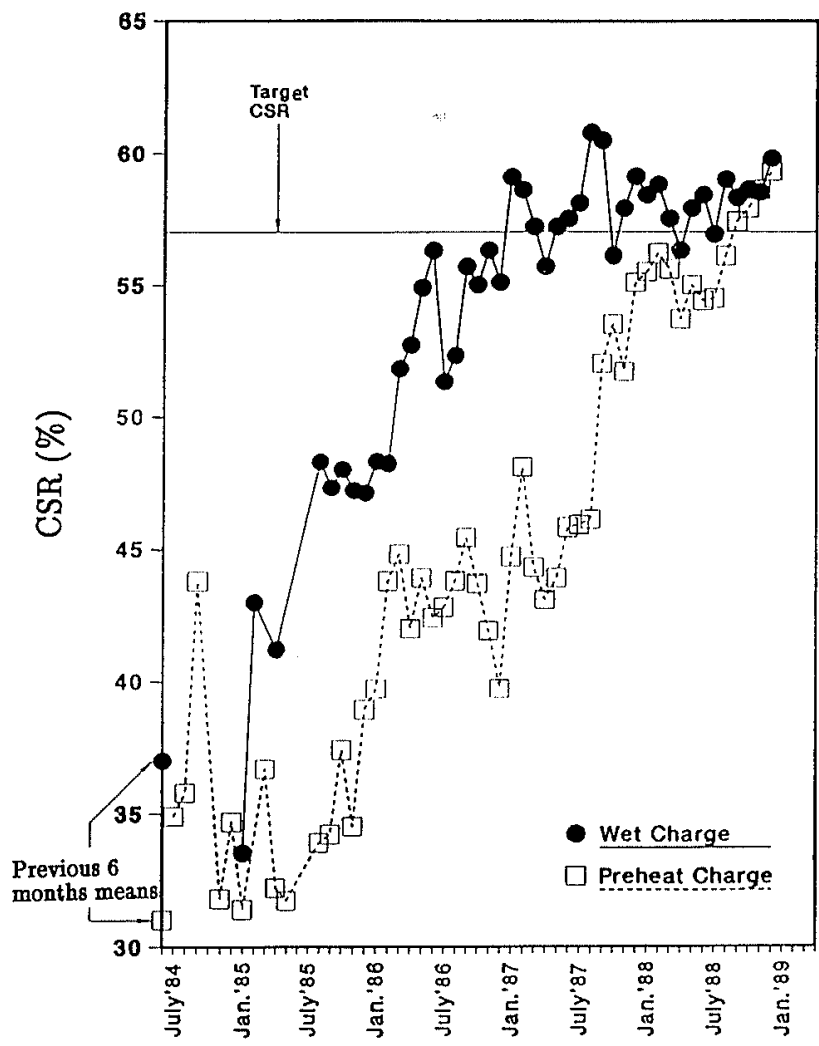

Fig. 4. The improvement of CSR values at Inland Steel.

ing at the time. The attention then centered on improving the by-product cokemaking process. Coal pre-heating technology was developed and adapted at a number of plants. Quenching improvements were implemented to reduce coke moisture. Battery heating was improved to reduce heat consumption. In the mid 1980's, CSR was recognized as an important quality parameter. Coal selection techniques were developed to improve this property. An example of this improvement at Inland Steel is shown in Fig. 4.8)

As the environmental regulations became more stringent, major investments were made during the 1980's to achieve compliance. Environmental regulations are expected to tighten even further. Investments needed to meet the new regulations and 
increasing operating costs have created uncertainty in the viability of a number of these aged coke batteries.

\section{A Review of the Operations of Some Large Blast Furnaces}

Inland Steel's No. 7 Blast Furnace at the Indiana Harbor Works and Bethlehem Steel's "L" Blast Furnace at Sparrows Point are the two largest blast furnaces in North America. Both furnaces were designed in the 1970's and blown-in towards the end of the decade. Although both blast furnaces are 4000 $\mathrm{m}^{3}$-class and share a number of design features (e.g., bell-less top), there are significant differences in the raw materials used.

The No. 7 Blast Furnace was blown-in with a burden of $75 \%$ acid pellets and $25 \%$ sinter. This was the first time such a large proportion of acid pellets was used in a $4000 \mathrm{~m}^{3}$-class blast furnace and burden distribution practices had to be specifically developed in this case. Hot spots were observed in the lower stack area about 18 months after the blown-in. As a result, grouting was used during the remaining 5 years of the campaign. The cause of the furnace ineffciency was diagnosed to be related to the inferior high temperature properties of acid pellets, super-fluxed sinter and coke. The coke CSR was improved by changing the coal blend and the furnace operation was stabilized. The second campaign of the furnace started with a burden consisting of limestone-dolomite fluxed pellets and medium-basicity sinter. This allowed the development of standardized control procedures for solution loss and permeability. In the second campaign, the furnace was operating at $20 \%$ higher productivity and $8 \%$ lower fuel rate, relative to the monthly record attained in the first campaign.9) A comparison of furnance profile and cooling system for the first and second campaign of this furnace are shown in Fig. 5.

The " L" Blast Furnace was blown-in with a burden consisting of about $55 \%$ acid pellets and $45 \%$ sinter. The coke quality was excellent with a high stability and CSR. The furnace experienced some hot spots initially, but these were rectified by changing the stockline profile and the burden distribution. Subsequently, the proportion of sinter in the burden was gradually increased to $65 \%$ in 1982, and this significantly improved blast furnace performance ${ }^{3)}$ as shown in Table 4. During the low hot metal demand period (1982-1986), raw material quality requirements (e.g., coke stability and size) were relaxed. Furnace operation was satisfactory during this time period. ${ }^{10)}$ As the hot metal demand increased in subsequent years, raw material quality had to be enhanced in order to maintain a stable furnace operation.

Typical operating data for the two largest blast furnaces in North America is shown in Table 5. As shown, these furnaces presently rank amongst the most efficient blast furnace operations in the world. The data also demonstrates that excellent blast furnace performance can be attained with a high proportion of pellets in the burden.

\section{A Review of the Operations of Some Medi- um Size Blast Furnaces}

\subsection{Burns Harbor $D$ and $C$ of Bethlehem Steel ${ }^{11}$}

Burns Harbor Plant was built on a greenfield with Blast Furnace D blown-in during 1969 and C in 1972.

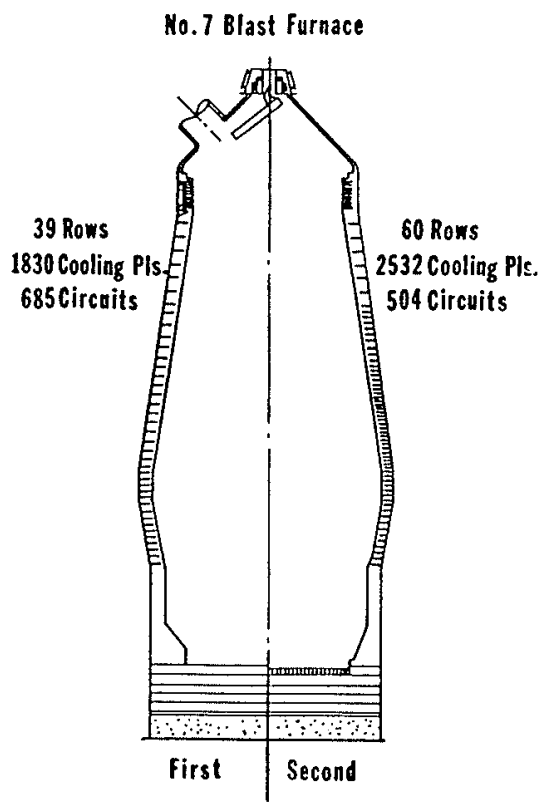

\begin{tabular}{llcc}
\hline \multirow{2}{*}{ Area } & \multicolumn{2}{c}{ Campaign } \\
\cline { 3 - 4 } Bosh & & First & Second \\
& Rows & 10 & 11 \\
& Plates & 600 & 440 \\
& Circuits & 300 & 110 \\
& Vert. spacing & $406 \mathrm{~mm}$ & $385 \mathrm{~mm}$ \\
\hline Belly & Rows & 5 & 7 \\
& Plates & 300 & 328 \\
& Circuits & 150 & 58 \\
& Vert. spacing & $508 \mathrm{~mm}$ & $312 \mathrm{~mm}$ \\
\hline \multirow{2}{*}{ L. stack } & Rows & 10 & 21 \\
& Plates & 480 & 1008 \\
& Circuits & 160 & 168 \\
& Vert. spacing & $508 \mathrm{~mm}$ & $250 \mathrm{~mm}$ \\
\hline \multirow{2}{*}{ M. stack } & Rows & $2 ; 6$ & $6 ; 1 ; 8$ \\
& Plates & 306 & 612 \\
& Circuits & 51 & 144 \\
& Vert. spacing & $609 ; 813$ & $312 ; 373 ; 406$ \\
\hline U. stack & Rows & 6 & 6 \\
& Plates & 144 & 144 \\
& Circuits & 24 & 24 \\
& Vert. spacing & $914 \mathrm{~mm}$ & $914 \mathrm{~mm}$ \\
\hline
\end{tabular}

Fig. 5. A comparison of furnace profile and cooling system for the first and second campaign of Inland's No. 7 Blast Furnace. 
Table 5. Recent performance of the largest blast furnaces in North America.

\begin{tabular}{|c|c|c|c|}
\hline \multicolumn{2}{|c|}{ Company, Plant, Furnace } & $\begin{array}{c}\text { Inland } \\
\text { Indiana } \\
\text { Harbor } \\
\text { No. } 7\end{array}$ & $\begin{array}{c}\text { Bethlehem } \\
\text { Sparrow } \\
\text { Point } \\
\text { "L" }\end{array}$ \\
\hline \multicolumn{2}{|c|}{ Hearth diameter $(\mathrm{m})$} & 13.7 & 13.6 \\
\hline \multicolumn{2}{|c|}{ Production (THM/d) } & 8581 & 8287 \\
\hline \multicolumn{2}{|c|}{ Productivity (THM $/ \mathrm{d} / \mathrm{m}^{3} \mathrm{WV}$ ) } & 2.30 & 2.24 \\
\hline \multicolumn{2}{|c|}{ Coke rate $(\mathrm{kg} / \mathrm{THM})$} & 422 & 423 \\
\hline \multicolumn{2}{|c|}{ Natural gas injection (kg/THM) } & 28 & 33 \\
\hline \multicolumn{2}{|c|}{ Total fuel rate $(\mathrm{kg} / \mathrm{THM})$} & 450 & 456 \\
\hline \multirow[t]{4}{*}{ Hot metal $(\%)$} & $\mathrm{Si}$ & 0.37 & 0.53 \\
\hline & $\mathrm{S}$ & 0.038 & 0.027 \\
\hline & $\mathrm{P}$ & 0.030 & 0.050 \\
\hline & Mn & 0.39 & 0.60 \\
\hline \multirow[t]{3}{*}{ Burden (\%) } & Sinter & 13 & 63 \\
\hline & Pellets & 84 & 37 \\
\hline & $\begin{array}{l}\text { Ore, Miscella- } \\
\text { neous }\end{array}$ & 3 & 0 \\
\hline \multicolumn{2}{|c|}{ Slag volume $(\mathrm{kg} / \mathrm{THM})$} & 266 & 249 \\
\hline \multicolumn{2}{|c|}{ Top gas $\mathrm{CO} / \mathrm{CO}_{2}$ ratio $(-)$} & 0.90 & 0.97 \\
\hline
\end{tabular}

They were designed to produce $4545 \mathrm{THM} / \mathrm{d}$ on a $100 \%$ acid pellets burden at fuel rates around 550 $\mathrm{kg} / \mathrm{THM}$. For 1989 each furnace was producing over $6363 \mathrm{THM} / \mathrm{d}$ and a fuel rate below $470 \mathrm{~kg} / \mathrm{THM}$ with 35-40\% superfluxed sinter and 60-65\% Hibbing acid pellets. The working volume of two furnaces are essentially the same, $2510 \mathrm{~m}^{3}$, even though the hearth diameters are different, $11.7 \mathrm{~m}$ for $\mathrm{G}$ and $10.7 \mathrm{~m}$ for $\mathrm{D}$. These furnaces are equipped with high top pressure (1.12 atm), two tapholes, computer control stockhouses with conveyor filling and high temperature stoves. Figs. 6 and 7 show major events in the last two decades.

Extensive work on coke quality and blast furnace performance at Bethlehem Steel have been carried out. ${ }^{10)}$ In Burns Harbor during early 1988, coke stability dropped from 59.3 to $57.8 \%$ which caused reduced permeability and maximum wind volume, impaired drainage, increased in burnt cooling plates, lower hot metal quality and the inability to operate at the previously normal flame temperature. These aforementioned difficulties were eliminated and normal performance restored with the return to levels of coke stability approaching $60 \%$ by the late spring. Improvements in burden distribution and the building of the third $\mathrm{BOF}$ vessel have contributed to the success. In the near future, the goal is $7300 \mathrm{THM} / \mathrm{d}$ for each of both furnaces and coal injection will be introduced.

\subsection{Armoo's Middletown No. 3 Blast Furnace ${ }^{12)}$}

The major ironmaking unit of the company have been modernized to achieve a productivity of 2.6 $\mathrm{THM} / \mathrm{d} / \mathrm{m}^{3} \mathrm{WV}$ and a carbon rate (not coke rate) of $462 \mathrm{~kg} / \mathrm{THM}$ through improvements in equipment, raw materials and burden distribution, cast house practice, etc. Basic dimensions of this furnace, and comparative performance in 1982 and 1988 are given in Fig. 8. The physical evolution of this furnace with dates for major events are shown in Fig. 9.

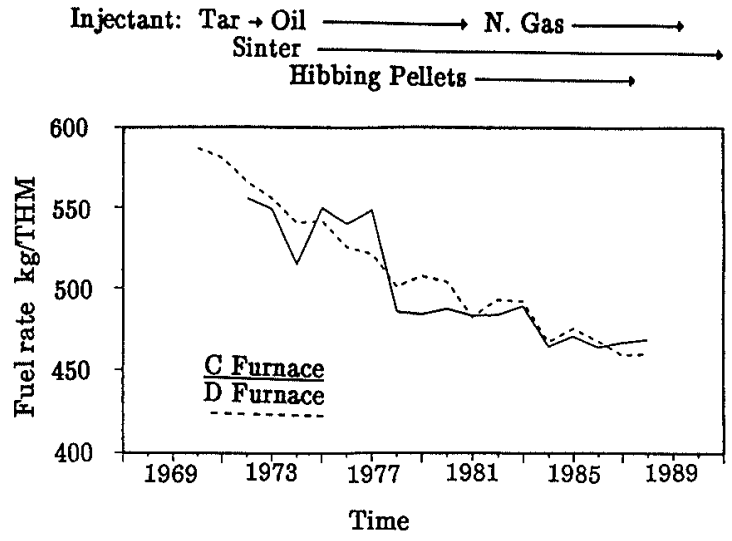

Fig. 6. Burns Harbor Blast Furnaces-Annual fuel rate.

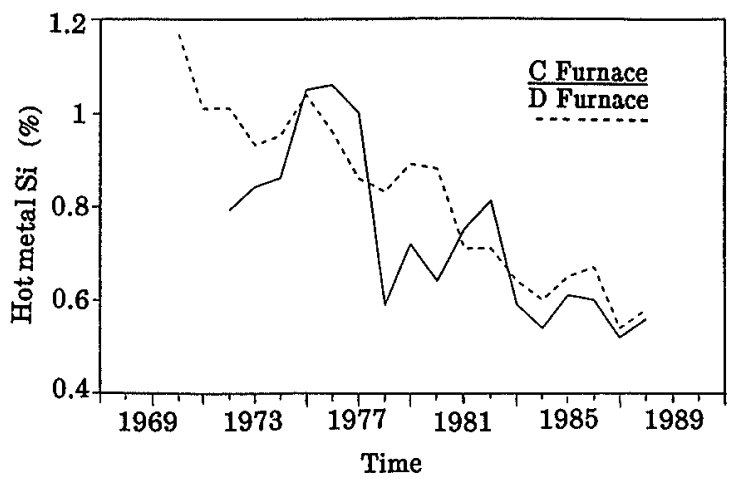

Fig. 7. Burns Harbor Blast Furnaces-Annual data for hot metal Si content.

The replacement of bentonite by organic binder in the making of pellets ( $55 \%$ of burden) which resulted in an increase in porosity, reducibility and softening temperature, has been beneficial. When the basicity of sinter was lowered from 3 to 2 , an increase in the burden from 35 to $45 \%$ occurred. Coke stability and CSR index were maintained at about $60 \%$, and 57 to $59 \%$, respectively. Improvement of raw materials quality and consistency have been credited for lower heat flux to walls and anticipated extension of lining life. The changes in the consistency of hot metal chemistry are shown in Table 6.

\subsection{Dofasco's No. 4 Blast Furnace ${ }^{13)}$}

It was commissioned in 1971 , with an $8.5 \mathrm{~m}$ hearth, and recently rebuilt in 1986 . It has two tapholes, bell-less top, new cast house and a cooling system that integrates a dense spacing of cooling plates with a refractory lining of graphite/semi graphite and silicon carbide for an expected campaign life of 10 years. The operating conditions of this furnace for 1987 are shown in Table 7. The events of the introduction of hot metal desulfurization, improvements in coke stability, lower silicon hot metal and fluxed pellets on fuel rate are shown in Fig. 10.

At the present time, it is run on $20 \%$ Wabush acid pellet and $80 \%$ fluxed pellets. The acid pellets have $3.1 \% \mathrm{SiO}_{2}, 1.95 \% \mathrm{Mn}$ and high reducibility and softening temperature. During the 1985 trials, it was found that the decrease in the fuel rate, due to the use of $75 \%$ fluxed pellets in the burden, was $31 \mathrm{~kg} /$ 


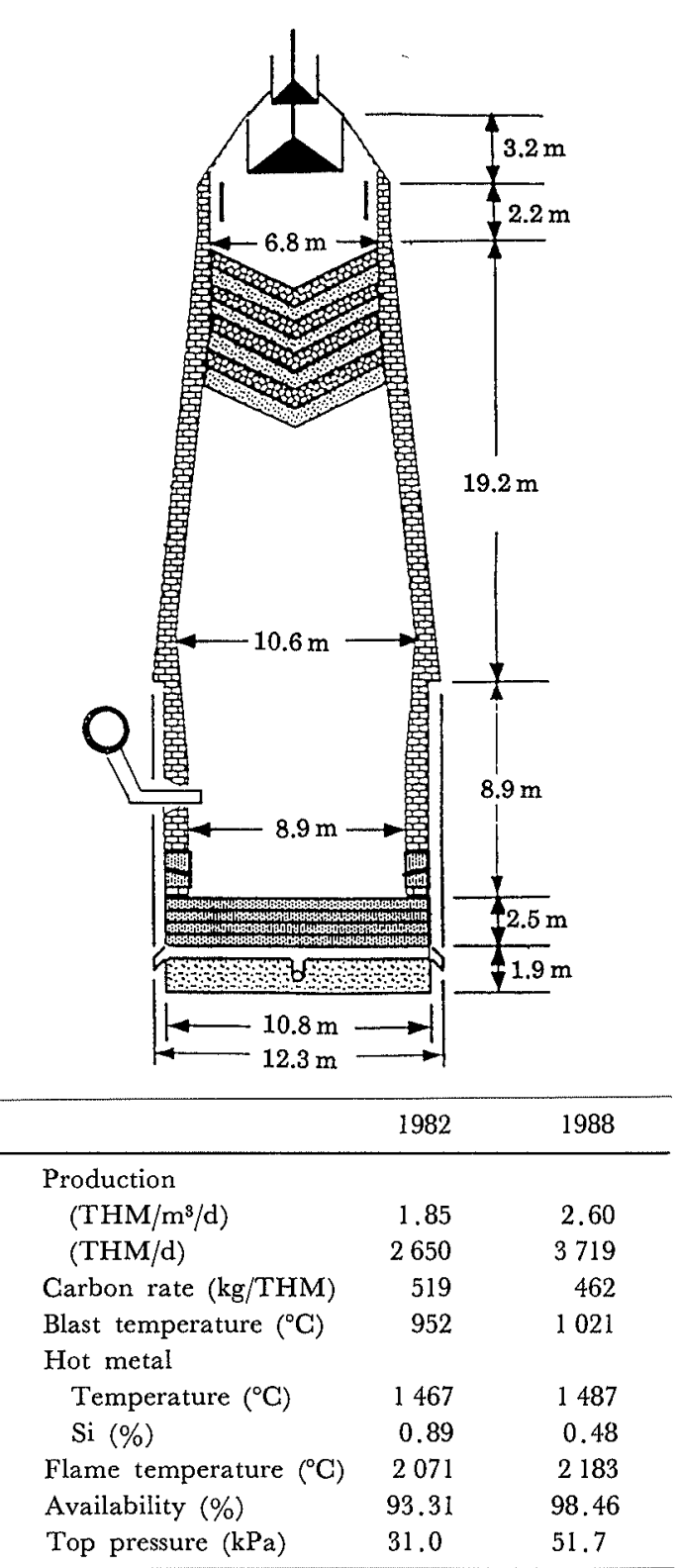

Fig. 8. Middletown No. 3 Blast Furnace general characteristics.

Table 6. Changes in hot metal quality of Middletown No. 3 Blast Furnace.

\begin{tabular}{lll}
\hline \multicolumn{1}{c}{ Process variables } & \multicolumn{2}{c}{ Standard deviation $(\%)$} \\
\hline & $\mathbf{1 9 8 2}$ & $\mathbf{1 9 8 8}$ \\
Hot metal silicon & 0.16 & 0.086 \\
Hot metal sulphur & 0.016 & 0.009 \\
Hot metal manganese & 0.06 & 0.04 \\
Hot metal phosphorus & 0.004 & 0.003 \\
\hline
\end{tabular}

\section{THM.}

In future planning, the goals of the current efforts in higher blast temperature, lower silica in pellets, dehumidification of blast, etc. are listed in Table 8.

\section{Future Development}

With further tightening of environmental standards and increasing capital and operating costs of the relatively old coke batteries, there is a strong interest in

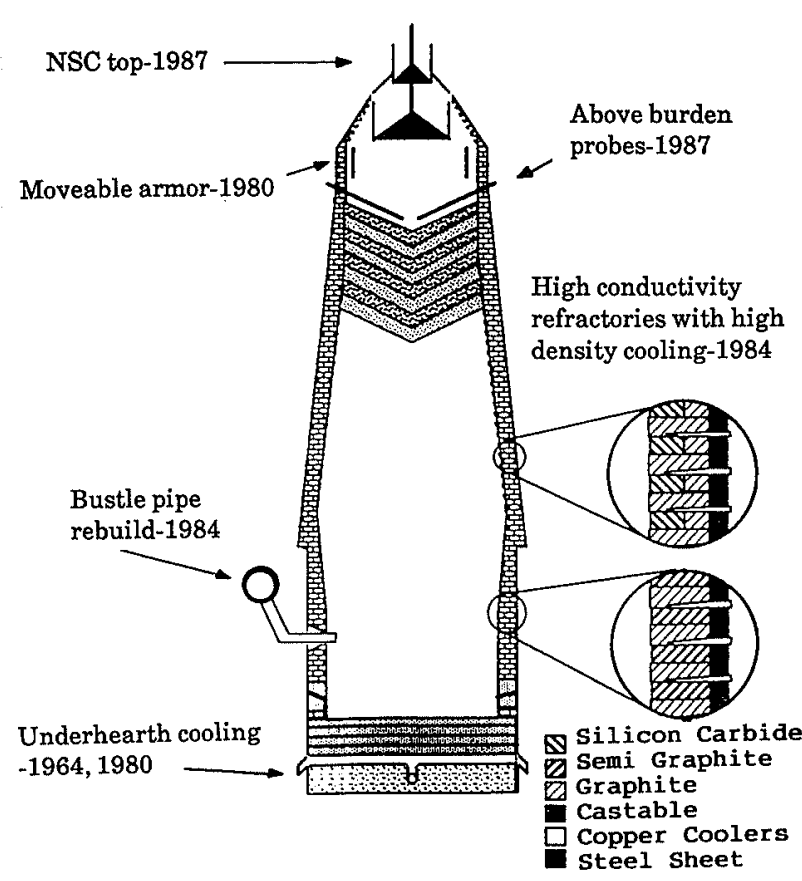

Sinter plant constructed: 1975

Slag pits: 1982

New cast house: 1984

Fourth stove: 1967

Stockhouse automation: 1984

Coke moisture gauges: 1983

Kovarhar supervisory system: 1986

Skip volume increased $33 \%$ : 1984

Fig. 9. The physical evolution of the Middletown No. 3 Blast Furnace.

Table 7. No. 4 Blast Furnace perfomance at Dofasco in 1987.

\begin{tabular}{|c|c|c|c|}
\hline \multirow{3}{*}{ Burden } & Acid pellets & (\%) & 21.4 \\
\hline & Fluxed pellets & $(\%)$ & 78.6 \\
\hline & Scrap & $(\%)$ & 0.0 \\
\hline \multirow[t]{3}{*}{ Flux } & BOF slag & $(\mathrm{kg} / \mathrm{THM})$ & 33 \\
\hline & Dolomite & $(\mathrm{kg} / \mathrm{THM})$ & 25 \\
\hline & Bauxite & $(\mathrm{kg} / \mathrm{THM})$ & 13 \\
\hline \multirow[t]{4}{*}{ Fuel } & Coke & $(\mathrm{kg} / \mathrm{THM})$ & 434 \\
\hline & Oil & (kg/THM) & 47 \\
\hline & Tar & $(\mathrm{kg} / \mathrm{THM})$ & 0 \\
\hline & Total & $(\mathrm{kg} / \mathrm{THM})$ & 481 \\
\hline \multirow[t]{4}{*}{ Blast } & Temperature & $\left({ }^{\circ} \mathrm{C}\right)$ & 1015 \\
\hline & Moisture & $\left(\mathrm{g} / \mathrm{Nm}^{3}\right)$ & 19 \\
\hline & Oxygen & $(\%)$ & 21.5 \\
\hline & Volume & $\left(\mathrm{Nm}^{3} / \mathrm{THM}\right)$ & 1272 \\
\hline \multirow[t]{2}{*}{ Production } & Productivity & $\left(\mathrm{THM} / \mathrm{d} / \mathrm{m}^{3} \mathrm{WV}\right)$ & 2.14 \\
\hline & Downtime & $(\%)$ & 7.0 \\
\hline \multirow[t]{4}{*}{ Hot metal } & Silicon & $(\%)$ & 0.53 \\
\hline & Manganese & $(\%)$ & 0.63 \\
\hline & Sulphur & $(\%)$ & 0.065 \\
\hline & Temperature & $\left({ }^{\circ} \mathrm{C}\right)$ & 1469 \\
\hline \multirow[t]{2}{*}{ Slag } & Volume & $(\mathrm{kg} / \mathrm{THM})$ & 203 \\
\hline & $(\mathrm{CaO}+\mathrm{MgO}) /($ & $\left(\mathrm{SiO}_{2}+\mathrm{Al}_{2} \mathrm{O}_{3}\right)$ & 1.09 \\
\hline \multirow[t]{4}{*}{ Top gas } & $\mathrm{CO}$ & $(\%)$ & 20.2 \\
\hline & $\mathrm{CO}_{2}$ & $(\%)$ & 21.3 \\
\hline & $\mathrm{H}_{2}$ & $(\%)$ & 2.6 \\
\hline & Temperature & $\left({ }^{\circ} \mathrm{C}\right)$ & 186 \\
\hline
\end{tabular}




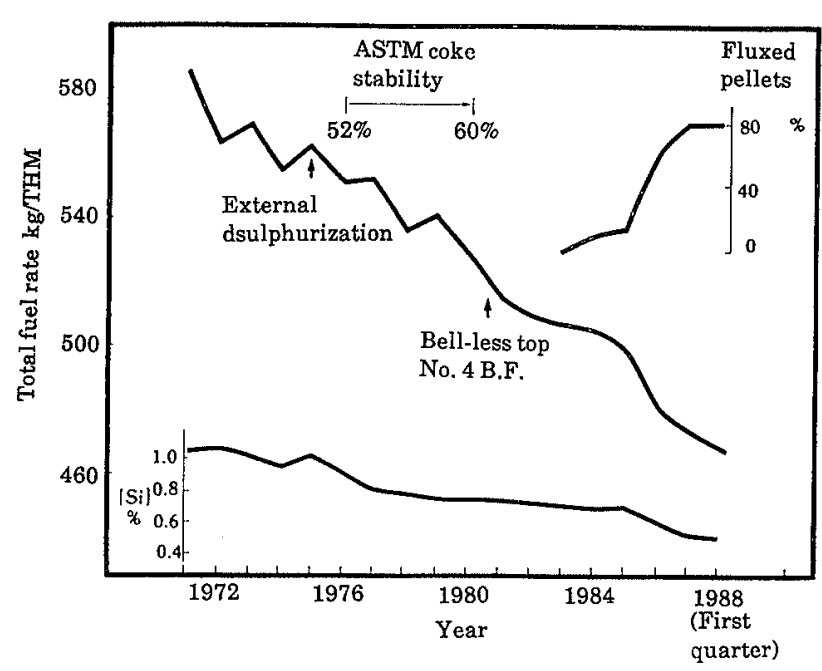

Fig. 10. Evolution of the blast furnace fuel rate at Dofasco.

Table 8. Future aims of blast furnace operation in Dofasco.

\begin{tabular}{lcc} 
& Current & Future \\
\hline Hot metal Si $(\%)$ & 0.45 & 0.30 \\
Hot metal Mn $(\%)$ & 0.60 & 0.30 \\
Blast temperature $\left({ }^{\circ} \mathrm{C}\right)$ & 980 & 1100 \\
Blast moisture $\left(\mathrm{g} / \mathrm{Nm}^{3}\right)$ & 19 & 11 \\
Slag volume $(\mathrm{kg} / \mathrm{THM})$ & 225 & 150 \\
Fuel rate $(\mathrm{kg} / \mathrm{THM})$ & 475 & $410-430$ \\
\hline
\end{tabular}

reducing coke requirements in ironmaking. At present, only Armco's Ashland plant employs blast furnace coal injection. A number of coal injection systems coming on stream are anticipated during the next 5 years. With the increasing emphasis on long campaign life and stable and efficient operations, there is a clear need to acquire and interpret realtime data concerning processes inside the blast furnace. In the near future, additional sensors, such as the in-burden probe in the upper stack, and on-site mathematical models and expert system-based tools will be available, to guide blast furnace operators and engineers.

Recently, environmentally-safe alternatives to the by-product cokemaking process are also being investigated. ${ }^{14)}$ It is possible that some plants using unconventional processes, such as non-recovery/heatrecovery cokemaking and formed coke, will be built in the next decade to replace the aged coke batteries.

Coke-less ironmaking processes, such as the COREX, ${ }^{15)}$ may also be built in plants, where byproduct energy can be economically utilized. Concerning research and development, a trend is being developed that steel companies, government and universities work together on certain major projects. The well known example in ironmaking area is the AISI Direct Steelmaking Project. ${ }^{16)}$ This smelting reduction project is being carried out by a Task Force under AISI and assisted by 4 universities (MIT and Carnegie-Mellon in the USA, and McMaster and McGill in Canada) with major funding from the Department of Energy, Washington, D.C. There are two projects which are in the formative stage.
AISI, on behalf of American Steel companies, has established a Task Force on Alternative Cokemaking Technology. A strategic study of future ironmaking processes which is sponsored by Canadian Government, Canadian steel and coal industries, just recently completed.

The 1990's present many challenges, and exciting technological developments in all aspects of ironmaking technology are to be expected.

\section{Conclusions}

(1) The improvements made in blast furnace operations in recent years in North America are mainly due to better raw materials.

(2) In next decade coal injection will be practiced widely to lower operational cost and coke rate.

(3) For more sophisticated operations in the future the use of sensors and mathematical models will be found to be advantageous.

\section{Acknowledgment}

The authors wish to express their appreciation to the Technical Committee on Blast Furnace Practice of the American Iron and Steel Institute for their assistance in conducting the survey of 1989 Blast Furnace Operations in the USA and Canada.

\section{REFERENCES}

1) "Third Annual Blast Furnace Roundup", Iron and Steelmaker, (1990), Aug., 22.

2) M. G. Ranade, J. A. Ricketts and J. B. Blattner: Ironmaking Proc., Vol. 43, AIME, Warrendale, PA, (1984), 267.

3) R. S. Hoffer, J. F. Syriste and J. J. Poveromo: Ironmaking Proc., Vol. 45, ISS-AIME, Warrendale, PA, (1986), 401.

4) R. L. Shultz, W.J. Snyder and J.H. Duncan: Burden Design for the Blast Furnace, McMaster Symp. No. 12, May 1984, W-K. Lu, ed., McMaster Univ., Hamilton, Ontario, (1984), 12.

5) D. D. Kaegi: Ironmaking Proc., Vol. 40, ISS-AIME, Warrendale, PA, (1981), 381.

6) W. L. Darrow, E. Saller and J. Poast: Iron Steel Eng., 50 (1973), 75.

7) P. K. Strangway and M. O. Holowaty: Agglomeration 77, ed. by K.V.S. Sastry, SME-AIME, New York, (1977), 1012.

8) H. S. Valia, D. D. Kaegi, V. I. Addes and D. A. Zuke: Ironmaking Conf. Proc., Vol. 48, ISS-AIME, Warrendale, PA, (1989), 133.

9) D. A. Zuke, J. A. Reimer, M. G. Ranade and P. B. Greenawald: Steel Technology International, P. H. Scholes, ed., Sterling Publications, (1989), 45.

10) J. J. Poveromo, N. D. Hodgson, E. L. Auslander and J. E. Lesko: McMaster Symp. No. 17, May 1989, W-K. Lu, ed., McMaster Univ, Hamilton, Ontario, (1989), 229.

11) J. A. Carpenter, R. F. Chango, D. E. Swanson and J.J. Poveromo: Ironmaking Conf. Proc., Vol. 48, ISS-AIME, Warrendale, PA, (1989), 347.

12) J. H. Duncan and R. L. Shultz: Int. Iron and Steel Inst. Meeting, Brussels, Belgium, June 8-9, 1988.

13) B. E. Aranha: Int. Iron and Steel Inst. Meeting, Brussels, Belgium, June 8-9, 1988.

14) G. Nashan: Cokemaking Int., 2 (1990), 19.

15) W. Maschlanka and J. Flikenschild: Iron Steel Eng., 67 (1990), 21.

16) E. Aukrust and K. B. Downing: Ironmaking Conf. Proc., Vol. 49, ISS-AIME, Warrendale, PA, (1990), 639. 